\title{
PENEGAKAN HUKUM TINDAK PIDANA PEMILU TERHADAP PENGGUNAAN HAK PILIH ORANG LAIN
}

\author{
La Ode Hermanto ${ }^{1 *}$, Syamsul Bachri ${ }^{2}$, Winner A. Siregar ${ }^{3}$ \\ 1,2,3 Badan Pengawas Pemilihan Umum Kota Kendari, Kendari, Indonesia \\ *laodehermanto7@gmail.com (corresponding)
}

\begin{abstract}
This study aims to determine the implementation of the Kendari City Bawaslu Supervision of Voter Data on the use of voting rights in the 2019 general election and to analyze the enforcement of general election law against the use of other people's voting rights in the 2019 general election. This research method uses empirical normative legal research. . The results of the study show that in carrying out its functions and authorities, the Kendari City Bawaslu has not shown optimal performance in the 2019 General Election, as evidenced by; there are still voters who do not meet the requirements are still being recorded, there are still eligible voters who are not registered in the voter list, lower-level technical implementing officers have not shown good work due to understanding of regulations that can change at any time, the professional level of the organizers' work, and the process supervision is not optimal due to limited supervisory personnel. As a recommendation, the Kendari City Bawaslu needs to improve the quality of election management resources so that they can work professionally, accountably, reliably and accurately and with integrity in the next election process.
\end{abstract}

Keywords: Election; Criminal Act; Right to Vote; Bawaslu; Kendari City

\section{PENDAHULUAN}

Pemilu adalah kompetisi untuk memperebutkan jabatan-jabatan politik yang memungkinkan pemenangnya untuk mengakses sumber daya politik dan ekonomi (Tanthowi, 2018)(Ardipandanto, 2019)(Al-fatih, 2020). Oleh karena itu peserta pemilu akan melakukan segala cara apapun entah itu melanggar hukum atau tidak yang penting tujuannya dapat tercapai sebagai pemenang pemilu. Lopez-Pintor membagi pelanggaran pemilu dalam 2 (dua) jenis yaitu Outcome determinative fraud (pelanggaran yang menentukan hasil-hasil pemilu) dan nonoutcome determinative fraud (pelanggaran yang tidak menentukan hasil-hasil pemilu) (Rahmatunnisa, 2017).

Terhadap pelanggaran pemilu di Indonesia Bawaslu RI telah merilis data yaitu 16.427 pelanggaran administrasi, 426 pelanggaran kode etik, 2.798 pelanggaran pidana, 1.518 pelanggaran hukum lainnya (Tumpal HS, 2019). Dari data tersebut menunjukan bahwa pelanggaran pemilu dapat dilakukan oleh siapa pun baik dari peserta pemilu, tim kampanye, penyelenggara pemilu, pemerintah, masyarakat, dan lain-lain.

Khususnya Bawaslu Kota Kendari pada Pemilihan Umum Tahun 2019, telah melakukan Penanganan Pelanggaran dengan jumlah 4 (empat) laporan dengan rincian; 3 (tiga) laporan 
dugaan pelanggaran pidana pemilihan umum dan 1 (satu) laporan pelanggaran kode etik (Bawaslu Kendari, 2019). Laporan Dugaan Pelanggaran (Wilar, 2019) yang selanjutnya disebut Laporan adalah laporan langsung Warga Negara Indonesia yang mempunyai hak pilih, Peserta Pemilu, atau pemantau Pemilu kepada Bawaslu dan/atau Bawaslu Kabupaten/Kota, Panwaslu Kecamatan, Panwaslu Kelurahan/Desa, Panwaslu LN, dan/atau Pengawas TPS pada setiap tahapan Penyelenggaraan Pemilu (Pasal 1 angka 26 Perbawaslu Nomor 7 Tahun 2018).

Terhadap tindak lanjut temuan dugaan pelanggaran Pidana Pemilu (Salabi, 2019) pada tahapan Pemilihan Umum Tahun 2019, bawa Bawaslu Kota Kendari juga telah melakukan proses penanganan temuan dugaan pelanggaran tindak pidana pemilu pada Tahapan Pemungutan Suara sejumlah 1 (satu) temuan Terlapor pada saat pemungutan suara mengaku dirinya sebagai orang lain untuk menggunakan hak pilih di TPS 07 Kel. Wundudopi Kec. Baruga Kota Kendari pada Tanggal 17 April 2019 sebagaimana dimaksud dalam Pasal 533 Undang-Undang No. 7 Tahun 2017. Setiap orang yang dengan sengaja pada saat pemungutan suara mengaku dirinya sebagai orang lain dan/atau memberikan suaranya lebih dari 1 (satu) kali di 1 (satu) TPS atau lebih dipidana dengan pidana penjara paling lama 1 (satu) tahun 6 (enam) bulan dan denda paling banyak Rp18.000.000,00 (delapan belas juta rupiah).

Perbuatan ini juga berakibat pada seluruh surat suara atau seluruh pemilih di TPS yang telah menggunakan hak pilihnya dianggap tidak sah dan batal demi hukum dan berakibat pada Pemungutan Suara Ulang (PSU) (Bawaslu Kendari, 2019). Maka dengan demikian, berdasarkan Fakta-fakta di atas membuat penelitian ini semakin menemukan arti penting untuk dilakukan. Dengan kata lain, penelitian ini sesungguhnya bermaksud untuk memotret pelaksanaan kewenangan yang dilakukan Bawaslu Kota Kendari yaitu sisi penegakan hukum khusnya pada kasus dugaan pelanggaran penggunaan hak pilih orang lain kemudian fakta tersebut ditindaklanjuti menjadi fakta hukum melalui prosedur pembuktian yang profesional.

Bawaslu Kota Kendari sebagai lembaga khusus yang berkaitan terhadap dugaan pelanggaran ini menjelaskan bahwa alat bukti seperti dimaksud oleh dapat dipenuhi dan ditindaklanjuti sebagai dugaaan pidana pemilihan umum tahun 2019 sesuai dengan ketentuan yang ada (Sahinuddin, 2021). Berdasarkan hal tersebut penulis, menarik untuk dikaji dan dijadikan karya ilmiah dengan judul "Penegekan Hukum Tindak Pidana Pemilu Terhadap Penggunaan Hak Pilih Orang Lain (Studi Di Bawaslu Kota Kendari)”.

\section{METODE PENELITIAN}

Dalam penulisam penelitian ini, metode yang digunakan yaitu penelitian hukum normatif empiris (Irwansyah, 2020), yang mana memadukan penelitian kepustakaan dengan dukungan data lapangan yaitu melalui wawancara terhadap pihak yang terkait termasuk wawancara terhadap para ahli hukum yang concern di bidangnya (Ramadani, 2009). Adapaun pokok kajian dalam penelitian ini adalah pelaksanaan atau implementasi ketentuan pidana pemilu pada peristiwa hukum yaitu pelanggaran pidana pemilu yaitu pengguaan hak pilih orang lain.

Adapun untuk memperoleh data dan informasi yang dibutuhkan, tempat penelitian dilakukan di Kantor Badan Pengawas Pemilihan Umum Kota Kendari. Sedangkan tehnik pengumpulan data dalam penelitian ini yaitu dilakukan dengan obeservasi dan interview terhadap bahan non hukum. Analis data yg digunakan dilakukan dengan analisis kualitatif juga 
dapat dilakukan analisis kuantitatif (terhadap data yang bersifat kuantitatif) dengan penyajian tabel, diagram maupun kurva (Soekanto \& Mamudji, 2015). Dalam menganalisis data dibutuhkan juga bahan hukum yang digunakan untuk menemukan jawaban atas permasalahan, proses analisis data dan bahan hukum merupakan proses menemukan jawaban dari pokok permasalahan yang timbul dari fakta hukum.

\section{HASIL DAN PEMBAHASAN}

Pada Tahapan Pemilihan Umum Tahun 2019 Bawaslu Kota Kendari, melakukan tugas pengwasan dan menemukan dugaan pelanggaran pidana pemilu, yaitu pelanggaran saat pemungutan suara mengaku dirinya sebagai orang lain untuk menggunakan hak pilih di TPS 07 Kel. Wundudopi Kec. Baruga Kota Kendari pada Tanggal 17 April 2019. Tentu perbuatan tersebut bertentangan dengan ketentuan Pasal 533 Undang-Undang Nomor 7 Tahun 2017 tentang Pemilihan Umum, bahwa: "Setiap orang yang dengan sengaja pada saat pemungutan suara mengaku dirinya sebagai orang lain dan/atau memberikan suaranya lebih dari 1 (satu) kali di 1 (satu) TPS atau lebih dipidana dengan pidana penjara paling lama 1 (satu) tahun 6 (enam) bulan dan denda paling banyak Rp18.000.000,00 (delapan belas juta rupiah)”.

Oleh karena itu Bawaslu Kota Kendari bersama-sama tim sentra Gakkumdu (Esfandiari \& Fatih, 2020)(Din et al., 2020) yaitu tim kejaksaan Negeri Kota Kendari dan penyidik Polres Kota Kendari menindak lanjuti temuan tersebut dengan terlebih dahulu memastikan syarat formil dan materil untuk dapat diterimanya setiap laporan. Adapun syarat formil meliputi:

1. Identitas pelapor/pihak yang berhak melaporkan;

2. Pihak terlapor;

3. Waktu pelaporan tidak melebihi ketentuan paling lama 7 (Tujuh) hari sejak diketahui terjadinya dan/atau ditemukannya dugaan pelanggaran Pemilu;

4. Kesesuain tanda tangan dalam formulir laporan dugaan pelanggaran dengan kartu tanda penduduk Elektronik dan/atau kartu identitas lain.

Kemudian syarat materil untuk dapat diterima laporan adalah:

1. Peristiwa dan uraian kejadian;

2. Tempat peristiwa terjadi;

3. Saksi yang mengetahui peristiwa;

Karena laporan tersebut telah terpenuhi syarat formil dan materil, maka Bawaslu Kota Kendari diberi nomor dan diregistrasi sebagai dugaan pelanggaran. Untuk diketahui bahwa apabila suatu laporan dugaan pelanggaran pidana belum memenuhi syarat formal dan syarat materiil maka Bawaslu Kota Kendari, memberikan kesempatan kepada pelapor untuk melengkapi persyaratan ters ebut paling lama 3 hari sejak laporan diterima. Apabila dalam waktu 3 hari pelapor juga tidak bisa melengkapi syarat formil dan syarat materil laporan maka Bawaslu Kota Kendari menghentikan proses penangan laporan. Kemudian Bawaslu Kota Kendari memberikan surat pemberitahuan kepada pelapor atau ditempel pada papan pengumuman di Kantor Bawaslu Kota Kendari.

Setelah syarat formal dan materil terpenuhi tim Sentra Gakkumdu yang terdiri dari Bawaslu Kota Kendari, Kejaksaan Negeri Kota Kendari, dan Penyidik Polres Kota Kendari melakukan pembahasan pertama untuk menetukan dugaan pasal yang akan digunakaan terhadap dugaan 
pelanggaran pidana pemilu, yaitu pelanggaran saat pemungutan suara mengaku dirinya sebagai orang lain untuk menggunakan hak pilih di TPS 07 Kel. Wundudopi Kec. Baruga Kota Kendari pada Tanggal 17 April 2019.

Pembahasan pertama Sentra Gakkumdu Bawaslu Kota Kendari dilakukan paling lama 1x24 jam terhitung sejak tanggal temuan atau laporan diterima dan diregistrasi oleh Bawaslu Kota Kendari. Selanjutnya Bawaslu Kota Kendari melakukan kajian paling lama 7 (tujuh) hari terhitung setelah temuan atau laporan diterima dan di registrasi, dan jika Bawaslu Kota Kendari memerlukan keterangan tambahan, penyusunan keterangan tambahan dan kajian dilakukan paling lama 14 (empat belas) hari kerja setelah temuan dan laporan diterima dan di registrasi (Sahinuddin, 2021).

Mengenai Tindak Pidana Pemilu, Dedi Mulyadi (Mulyadi, 2015) melakukan Redefinisi Tindak Pidana Pemilu terhadap pengertian tindak pidana pemilu menjadi dua kategori:

1. Tindak Pidana Pemilu Khusus adalah semua tindak pidana Pemilu yang berkaitan dengan pemilu dan dilaksakan pada tahapan penyelenggara pemilu baik yang diatur dalam undang-undang tindak pidana pemilu.

2. Semua tindak pidana pemilu umum adalah semua tindak pidana yang berkaitan dengan pemilu dan dilaksanakan pada tahap penyelenggara pemilu baik yang diatur dalam undang-undang pemilu maupun undang-undang tindak pidana pemilu dan penyelesaiannya diluar tahapan pemilu melalui peradilan umum.

Untuk menjamin pemilu yang bebas dan adil, diperlukan perlindungan bagi para pamilih, bagi para pihak yang mengikuti pemilu, maupun bagi rakyat umunya dari segala ketakutan, intimidasi, penyuapan, penipuan, dan praktik- praktik curang lainnya yang akan memengaruhi kemurnian hasil pemilihan umum. Jika pemilihan dimenangi melalui cara-cara curang (malpractices), sulit dikatakan bahwa para pemimpin atau para legislator yang terpilih diparlemen merupakan wakil-wakil rakyat dan pemimpin sejati.

Guna melindungi kemurnian pemilu yang sangat penting bagi demokrasi itulah para pembuat undang-undang telah menjadikan sejumlah perbuatan curang dalam pemilu sebagai suatu tindak pidana. Dengan demikian, undang-undang tentang pemilu disamping mengatur tentang bagaimana pemilu dilaksanakan, juga melarang sejumlah perbuatan yang dapat menghancurkan hakikat free and fair election itu serta mengancam pelakunya dengan hukuman (Surbakti, 2011).

Tindak Pidana Pemilu (Fahmi et al., 2020) adalah tindak pidana pelanggaran dan/atau kejahatan terhadap ketentuan tindak pidana Pemilu sebagaimana diatur dalam Undang-Undang tentang Pemilihan umum. Pada Tahapan Pemilihan Umum Tahun 2019 Bawaslu Kota Kendari, melakukan tugas pengwasan dan menemukan dugaan pelanggaran pidana pemilu, yaitu pelanggaran saat pemungutan suara mengaku dirinya sebagai orang lain untuk menggunakan hak pilih di TPS 07 Kel. Wundudopi Kec. Baruga Kota Kendari pada Tanggal 17 April 2019.

Tentu perbuatan tersebut bertentangan dengan ketentuan Pasal 533 Undang-Undang Nomor 7 Tahun 2017 tentang Pemilihan Umum, bahwa: "Setiap orang yang dengan sengaja pada saat pemungutan suara mengaku dirinya sebagai orang lain dan/atau memberikan suaranya lebih dari 1 (satu) kali di 1 (satu) TPS atau lebih dipidana dengan pidana penjara paling lama 1 (satu) tahun 6 (enam) bulan dan denda paling banyak Rp18.000.000,00 (delapan belas juta rupiah)”. 
Berdasarkan Formulir model A (Form Hasil Pengawasan), bahwa laporan proses Pemungutan dan Perhitungan Suara Pemilu Nomor : 005/lhp/ PM.00.00/IV/2019, dengan Tujuan Memastikan Tahapan proses pemungutan dan perhitungan suara dilaksanakan Sesuai dengan UU. No. 7 Tahun 2019 tentang pemilihan umum, maka ditemukan dugaan pelanggaran Pemilih bahwa yang tidak terdaftar dalam DPT dan DPTb Menyalurkan hak pilih dengan menggunakan C6-KPU milik orang lain, dengan demikian dari hasil pengawasan dan analisis dari pengawas Pemilu, ditemukan adanya pelanggaran Pada Proses Pemungutan Suara di TPS 07 Kelurahan Wunduddopi antara lain;

1. Terjadi Penggunaan C6-KPU milik orang lain.

2. Terjadi kelalaian Petugas KPPS, karena tidak memeriksa KTP atau surat keterangan lainnya saat pelaku menggunakan hak pilihnya di TPS 07 Kelurahan Wundudopi.

Berdasarkan Hasil pengawasan yang dimaksud maka Bawaslu Kota Kendari memberikan arahan kepada pengawas pemilihan umum Kecamatan untuk tetap memberikan hak memilih kepada orang yang telah digunakan hak pilihnya, selanjutnya melalui pengawas pemilu kecamatan memerintahkan pengawas pemilu kelurahan untuk melakukan penelusuran dalam hal mencari fakta dan keterangan atas kejadian proses pelaksanaan pemilihan di TPS 07 Kelurahan Wundudopi.

Fakta kejadian Proses pelaksanaan Pemungutan Suara di TPS 07 kelurahan Wundudopi yang dilaksanakan dengan rincian sebagai berikut :

1. Pembukaan dilaksanakan pada pukul 07,00 WITA

2. Pada Pukul 11.00 saudara DR. nomor ktp 7471030411750001 yang beralamat di kompleks Ruko Graha BNI Permai bersama anaknya saudara RFRM. NIK 7471031107010001 yang beralamat di kompleks Ruko Graha BNI Permai pada pukul 11.00 wita ingin menyalurkan hak pilihnya di TPS 7 Kelurahan Wundudopi Kecamatan Baruga Kota Kendari; namun ternyata namanya telah digunakan oleh orang lain;

3. Anggota KPPS tidak melakukan pemeriksaan KTP-El atau surat keterangan lainya sebagai pendukung C6 saat sdr SYl dan Saudara UM datang menggunakan hak pilihnya di TPS 07 Kelurahan Wundudopi

Berdasarkan fakta kejadian maka Badan pengawas pemilihan umum Kota Kendari menindaklanjuti dengan melakukan rapat pleno dengan memperhatikan keterpenuhan syarat sebagaimana ketentuan Pasal 4 ayat (3) Peraturan Badan Pengawas Pemilihan Umum Nomor 7 Tahun 2018 tentang Penanganan Temuan dan Laporan Pelanggaran Pemilihan Umum, maka diputuskan sebagai berikut :

1. Bahwa terhadap temuan tersebut memenuhi syarat formil dan materil untuk ditindaklanjuti dan diregister dalam proses penanganan pelanggaran ;

2. Bahwa berdasarkan point 1 maka terhadap temuan tersebut diteruskan kepada Divisi Hukum, Penanganan Pelanggaran dan Penyelesaian Sengketa Bawaslu Kota Kendari untuk dilakukan proses penanganan pelanggaran lebih lanjut yang dituangakan dalam berita acara model B2.

Selanjutnya bahwa untuk menetapkan perbuatan yang dimaksud maka Bawaslu Kota Kendari bersama-sama tim sentra Gakkumdu yaitu tim kejaksaan Negeri Kota Kendari dan penyidik Polres Kota Kendari menindak lanjuti temuan tersebut dengan melakukan pembahasan 
pertama guna memastikan syarat formil dan materil dugaan temuan tersebut. Adapun syarat formil meliputi:

1. Identitas pelapor/pihak yang berhak melaporkan;

2. Pihak terlapor;

3. Waktu pelaporan tidak melebihi ketentuan paling lama 7 (Tujuh) hari sejak diketahui terjadinya dan/atau ditemukannya dugaan pelanggaran Pemilu;

4. Kesesuain tanda tangan dalam formulir laporan dugaan pelanggaran dengan kartu tanda penduduk Elektronik dan/atau kartu identitas lain.

Kemudian syarat materil untuk dapat diterima laporan adalah:

1. Peristiwa dan uraian kejadian;

2. Tempat peristiwa terjadi;

3. Saksi yang mengetahui peristiwa;

Hal ini dilakukan dalam rangka penyamaan presepsi antara institusi penegak hukum Pemilu, walaupun tidak diatur dalam secara normatif dalam ketentuan Undang-Undang Nomor 7 Tahun 2017 Tentang Pemilihan Umum dan Peraturan Badan Pengawas Pemilihan Umum Nomor 7 Tahun 2018 Tentang Penanganan Temuan Dan Laporan Pelanggaran Pemiihan Umum serta Peraturan Badan Pengawas Pemilihan Umum Nomor 31 Tahun 2018 Tentang Sentra Penegakan Hukum Terpadu. Bahwa langkah konkrit yang diterapkan untuk menjawab permasalahan kecurangan yang dilakukan oleh pelaku kejahatan Pemilu pada TPS 07 Kelurahan Wundudopi adalah diarahkan pada proses penyelesaian dengan cara penanganan pelanggaran administratif pemilu dengan memberikan Rekomendasi untuk meleksanakan Pemungutan Suara Ulang (PSU) bagi peneyelenggara Teknis yaitu KPU dan jajaranya.

Untuk diketahui bahwa apabila suatu laporan dugaan pelanggaran pidana belum memenuhi syarat formal dan syarat materiil maka Bawaslu Kota Kendari, memberikan kesempatan kepada pelapor untuk melengkapi persyaratan tersebut paling lama 3 hari sejak laporan diterima. Apabila dalam waktu 3 hari pelapor juga tidak bisa melengkapi syarat formil dan syarat materil laporan maka Bawaslu Kota Kendari menghentikan proses penangan laporan. Kemudian Bawaslu Kota Kendari memberikan surat pemberitahuan kepada pelapor atau ditempel pada papan pengumuman di Kantor Bawaslu Kota Kendari.

Batasan waktu Penindakan Pelanggaran Tindak Pidana Undangn-Undang Nomor 7 Tahun 2017 Tentang Pemilihan Umum dan Peraturan Badan Pengawas Pemilihan Umum Nomor 7 Tahun 2018 Tentang Penanganan Temuan Dan Laporan Pelaggaran Pemiihan Umum mengatur waktu pelaporan yang disampaikan kepada Pengawas Pemilihan Umum yaitu sejak dugaan pelanggaran diketahui terjadi, yang mana terdapat rentang waktu maksimal 7 (tujuh) hari yang diberikan kepada Pelapor untuk menyampaikan laporan dan apabila telah melewati waktu 7 (tujuh) hari, Undang-undang Nomor 7 Tahun 2017 Tentang Pemilihan Umum dan Peraturan Badan Pengawas Pemilihan Umum Nomor 7 Tahun 2018 Tentang Penanganan Temuan dan laporan Pelaggaran Pemiihan Umum, maka Badan Pengawas Pemilihan Umum tidak dapat menerima laporan yang dilaporkan oleh Pelapor.

Tindak pidana Pemilihan Umum ("Pemilu") menurut Pasal 1 angka 2 Peraturan Mahkamah Agung Nomor 1 Tahun 2018 tentang Tata Cara Penyelesaian Tindak Pidana Pemilihan dan Pemilihan Umum ("Perma 1/2018") sebagai berikut: Tindak Pidana Pemilihan Umum yang selanjutnya disebut Tindak Pidana Pemilu adalah tindak pidana pelanggaran 
dan/atau kejahatan sebagaimana diatur dalam Undang - Undang No 7 Tahun 2017 Tentang Pemilihan Umum.

Karena laporan tersebut telah terpenuhi syarat formil dan materil, maka Bawaslu Kota Kendari melakukan pembaasan tingkat kedua dan hasil pembahasan dituangkan dalm berita acara rekomendasi atas kasus dugaan pelanggaran ditingkatkan ke tahap Penyidikan oleh penyidik Polres Kota Kendari, dalam hal penyidik Kepolisian melakukan penyelidikan terlebih dahulu kasus yang dimaksud diberi nomor laporan polisi dan diregistrasi sebagai dugaan pelanggaran pidana.

Selanjutnya Bawaslu Kota Kendari bersama penyidik dan jaksa melakukan pembahasan kedua, untuk membahas kajian Bawaslu Kota Kendari dan laporan hasil penyelidikan serta untuk menyimpulkan laporan yang diduga merupakan tindak pidana pemilu dalam Pasal Pasal 533 Undang Nomor 7 Tahun 2017 Tentang Pemilihan Umum bahwa ; Memberikan keterangan tidak benar dalam pengisian data diri daftar pemilih; Setiap orang yang dengan sengaja memberikan keterangan yang tidak benar mengenai diri sendiri atau diri orang lain terutang suatu hal yang diperlukan untuk pengisian daftar Pemilih sebagaimana dimaksud bahwa : Setiap orang yang dengan sengaja pada saat pemungutan suara mengaku dirinya sebagai orang lain dan/atau memberikan suaranya lebih dari 1 (satu) kali di 1 (satu) TPS atau lebih dipidana dengan pidana penjara paling lama 1 (satu) tahun 6 (enam) bulan dan denda paling banyak Rp18.000.000,00 (delapan belas juta rupiah).

Bahwa berdasarkan tindakan terlapor tersebut Bawaslu Kota Kendari menduga kuat sebagai bentuk pelanggaran pidana pemilihan umum sebagaimana ketentuan Pasal 533 Undang Nomor 7 Tahun 2017 Tentang Pemilihan Umum dengan demikian langkah-langkah yang diambil sesuai dengan peraturan bawaslu Nomor 7 Tahun 2018 Tentang Penanganan Temuan dan laporan Pelaggaran Pemiihan Umum maka prosedur yang dilakukan adalah mebuat kajian atas perbuatan yang dimaksud : adapun unsur- unsur dalam melakukan kajian beberapa point yang dilakukan, yaitu

1. Dasar Hukum :

a) Undang-UndangNomor7Tahun 2017 Tentang Pemilihan Umum:

b) Perbawaslu Nomor 7Tahun 2018 Tentang PenangananTemuan dan Laporan Pelanggaran Pemilihan Umum :

2. Analisis

Berdasarkan fakta dan keterangan di atas, maka terdapat beberapa point pembahasan/kajian sebagai berikut :
a) Tentang Temuan
b) TentangPenemu
c) Tentang Terlapor
d) Tentang Waktu Temuan
e) Tentang Dugaan Pelanggaran

Bahwa untuk membuktikan bahwa ada tidaknya pelanggaran pidana pemilu sebagaimana Pasal 523 ayat (1) Undang-Undang Nomor 7 Tahun 2017 dalam kasus a quo, perlu dikaji berdasarkan unsur-unsur dibawah ini:

1. Unsur setiap orang

a) Unsur dengan Sengaja (opzettelijk) 
b) Unsur pada saat pemungutan suara

c) Unsur mengaku dirinya sebagai orang lain

Setelah melakukan kajian terhadap dugaan pelanggaran atas temuan Nomor register 07/TM/LP/KOTA/28.01/IV/2019 dan setelah dihubungkan antara fakta, keterangan serta barang bukti dengan ketentuan perundang-undangan tentang pemilihan umum maka dapat disimpulkan bahwa kuat dugaan terlapor melakukan perbuatan tindak pidana pemilu berupa pelanggaran ketentuan Pasal 533U ndang-Undang Nomor 7 Tahun 2017 tentang Pemilihan Umum. Berdasarkan uraian Kajian dan Kesimpulan di atas, maka direkomendasikan hal-hal sebagai berikut: 1) Mengumumkan status Temuandengan menggunakan formulir model B.15 sebagaimana diatur dalam Peraturan Bawaslu Nomor 7 Tahun 2018 Tentang PenangananTemuan dan Laporan Pelanggaran Pemilihan Umum; dan 2) Meneruskannya kepada Kepolisian Resort Kota Kendari untuk dilakukan penyidikan.

Berdasarkan berita acara pembahasan ketiga sentra gakkumdu kota kendari nomor: /sg/ kota kendari/V/2019, tanggal 27 mei 2019 dan laporan polisi nomor: lp/142/v/2019/sultra/res kdi yang ditangani oleh penyidik kepolisian resort kendari maka sentra Gakkumdu melakukan pembahasan ketiga dengan membahas Hasil Penyidikan Bahwa proses penyidikan terhadap temuan dugaan Tindak Pidana Pemilu berupa mengaku dirinya sebagai orang lain untuk menggunakan hak pilih sebagaimana dimaksud dalam Pasal 533 Undang-Undang Nomor 7 Tahun 2017 tentang Pemilihan Umum dengan Pelapor (Pengawas TPS 7 Kel. Wundudopi) dan terlapor, telah dilakukan serangkaian pemeriksaan terhadap pelapor, saksi-saksi dan tersangka. Hasil pemeriksaan pada pokoknya semakin menguatkan bahwa telah terjadi peristiwa tindak pidana pemilu yang dilakukan oleh tersangka.

Bahwa fakta hukum telah terjadi tindak pidana pemilu sebagaimana diatas juga semakin diperkuat oleh bukti-bukti setelah dilakukan penyitaan terhadap Formulir Model C6 yang digunakan tersangka, Formulir Model C7-DPT, Formulir Model C7-DPK dan Formulir Model A3-KPU (Daftar Pemilih Tetap), sehingga penyidik menganggap bahwa perkara tersebut sudah dapat dilimpahkan ke Kejaksaan Negeri Kendari mengingat waktu 14 hari untuk melakukan penyidikan sudah akan berakhir.

Sedangkan terhadap pelaku kejahatan Terlapor pada Tanggal 17 April 2019 di TPS 07 Kel. Wundudopi Kecamatan Baruga Kota Kendari pada saat pemungutan suara dengan menggunakan hak pilih dengan cara mengaku dirinya sebagai orang lain, diarahkan sebagai tindak pidana umum sebagaimana diatur dalam hukum pidana, yang dikenal dengan istilah "ultimum remidium" Artinya sanksi pidana ditegakan jika sanksi-sanksi yang lain sudah tidak berdaya (Erdianti \& Al-Fatih, 2019). Dengan kata lain, dalam suatu undang-undang sanksi pidana dicantumkan sebagai sanksi yang terakhir, setelah sanksi perdata, maupun sanksi administratif.

Solusi ini disajikan yaitu agar selain memberikan kepastian hukum dan juga dapat memberikan keadilan baik terhadap korban maupun terhadap pelaku itu sendiri. Sudikno Mertokusumo (Mertokusumo, 2004) mengartikan bahwa ultimum remedium sebagai alat terakhir. Hal ini memiliki makna apabila suatu perkara dapat diselesaikan melalui jalur lain (kekeluargaan, negosiasi, mediasi, erdata, ataupun hokum administrasi) hendaklah jalur tersebut terlebih dahulu dilalui Pada Tahapan Pemilihan Umum Tahun 2019 oleh Bawaslu 
Kota Kendari khususnya Divisi Hukum, Penanganan Pelanggaran dan Penyelesaian Sengketa telah melakukan proses penanganan pelanggaran terhadap dugaan pelanggaran pidana pemilu.

Dugaan pelanggaran pada saat pemungutan suara yang mengaku dirinya sebagai orang lain untuk dapat menggunakan hak pilih di TPS 07 Kel. Wundudopi Kec. Baruga Kota Kendari pada Tanggal 17 April 2019 setelah dihubungkan antara fakta, keterangan serta barang bukti dengan ketentuan perundang-undangan tentang pemilihan umum maka dapat disimpulkan bahwa kuat dugaan terlapor telah melakukan perbuatan tindak pidana pemilu berupa pelanggaran. Jika dilihat menurut jenis pelanggaran maka jumlah kasus yang diproses oleh Bawaslu Kota Kendari sejumlah 12 (dua belas) kasus hal ini disebakan karena terdapat kasus yang bersumber dari 1 (satu) laporan namun hasil kajian menunjukkan terdapat 2 (dua) jenis pelanggaran.

Pada pasal tersebut, kalimat "setiap orang dengan sengaja mengaku dirinya sebagai orang lain" menunjukan bahwa ada tindakan atau perbuatan yang dapat merugikan orang lain yaitu menggunakan hak pilih orang lain dengan mengaku bahwa dirinya yang berhak menggunakan hak pilih pada Form. C6 (Surat pemberitahuan memilih), perbuatan ini tidak saja berdampak pada seseorang yang dirugikan karena hak pilihnya telah digunakan, ada perbuatan melanggar hukum pemilu yang menyebabkan hak seseorang untuk memilih tidak terpakai dan perbuatan ini pula dapat menyebabkan pemungutan suara ulang di TPS yang terkait.

Perbuatan ini juga berakibat pada seluruh surat suara atau seluruh pemilih di TPS yang telah menggunakan hak pilihnya dianggap tidak sah dan batal demi hukum (Sahinuddin, 2021). Dalam hal Penegakkan Hukum dan Unsur-unsur Penegakkan Hukum Pemilu, Penegakkan hukum adalah suatu usaha untuk menanggulangi kejahatan secara rasional, memenuhi keadilan dan berdaya guna, dalam rangka menanggulangi kejahatan terhadap berbagai sarana sebagai reaksi yang dapat diberikan kepada pelaku kejahatan, berupa sarana pidana maupun non hukum pidana, yang dapat diintegrasikan satu dengan yang lainya (Sahinuddin, 2021).

Maka dengan demikian, berdasarkan Fakta-fakta di atas bahwa proses pelaksanaan Pemilihan umum tahun 2019 ditemukan beberapa kelemahan pada pelaksanaan pemilihan umum, baik dari aspek regulasi, penyelenggara Pemilihan Umum Bawaslu dan KPU. Bahwa penyelenggara tekhnis ditingkat TPS dalam hal melaksanakan proses pemilihan umum ditingkat masih terdapat petugas dibeberapa TPS tidak memahamai terkait regulasi pemilhan umum, masih ada Petugas KPPS yang melakukan Pembukaan Kotak Suara dengan alasan untuk mengambil Formulir yang tertinggal dalam kotak suara,

Pengawas Pemilihan Umum ditingkat TPS dalam menjalankan tugas mengawasi proses pelaksanaan Pemilu ditingkat TPS mengalami keterbatasan sumber daya manusia dimana dalam setiap TPS hanya terdapat satu orang pengawas TPS yang bertugas mengawasi proses pelaksanaan Pemilihan Umum yang dilaksanakan oleh KPPS yang berangotakan sebanyak tujuh orang, tugas dari pengawas TPS memastikan pelaksanaan Pemilu apakah sesuai dengan ketentuan perundang-undangan, disisi lain juga Pengawasa Pemilihan Umum Tingkat TPS mengawasi pemilih, mengawasi tim pasangan calon dan calon anggota Legislatif serta mengawasi netralitas dari ASN tigkat kelurahan juga memastikan tidak ada potensi terjadinya poltik uang pada saat hari pemungutan suara tingkat TPS (Sahinuddin, 2021).

Hal tersebut perlu beberapa perbaikan baik aspek subtansi tentang kepemiluan, aspek subyek dan budaya terkait dengan sumber daya manusia penyelenggara pemilihan umum sehingga berdampak pada pelaksanaan penyelenggaraan pemilihan umum secara profesional dan 
berintegritas sesuai dengan amanah undang-undang kepemiluan dan ketentuan Tekhnis yang berlaku (Sahinuddin, 2021).

Ada 3 unsur yang harus diperhatikan dalam penegakan hukum, yaitu: Kepastian hukum (rechtssicherheit) (Saragih, 2017); Kepastian hukum merupakan perlindungan yustisiabel terhadap tindakan sewenang-wenang, yang berarti bahwa seseorang akan dapat memperoleh sesuatu yang diharapkan dalam keadaan tertentu. Masyarakat mengharapkan adanya kepastian hukum masyarakat akan lebih tertib (Adonara, 2015). 2. Kemanfaatan (zweckmassigkeit) (Wijayanta, 2014); dan Hukum adalah untuk manusia, maka hukum atau penegak hukum harus memberi manfaat atau kegunaan bagi masyarakat, jangan sampai timbul keresahan di dalam masyarakat karena pelaksanaan atau penegak hukum. 3. Keadilan (gerechtigkeit) (Likadja, 2015). Hukum itu tidak identik dengan keadilan (Aulia \& Al-Fatih, 2017). Hukum itu bersifat umum, mengikat setiap orang, bersifat menyamaratakan. Sebaliknya keadilan bersifat subyektif, individualistis, dan tidak menyamaratakan (Prasetyo \& Halim, 2005).

\section{KESIMPULAN}

Berdasarkan atas analisis diatas, dapat disimpulkan beberapa hal sebagai berikut: 1) Bahwa dalam melaksanakan fungsi dan kewenangan Bawaslu melakukan belum menunjukan kinerja yang optimal pada pelaksanaan Pemilu tahun 2019, dibuktikan dengan ; masih adanya data pemilih yang tidak memenuhi syarat masih terdata, masih ada pemilih yang memenuhi syarat tidak terdaftar dalam daftar pemilih, petugas pelaksana tekhnis tingkat bawah belum menunjukan kerja yang baik disebabkan pemahaman terhadap regulasi yang setiap saat dapat berubah, tingkat profesional kerja penyelenggara, serta proses pengawasan kurang maksimal karena keterbatasan personil pengawas, untuk itu perlu peningkatan kualitas sumber daya penyelenggara pemilu sehinggah dapat bekerja profesional, akuntabel, terpecaya dan akurat serta berintegritas pada proses pemilu selanjutnya. 2) Dengan adanya kasus penggunaan hak pilih orang lain pada pemilihan umum 2019, menunjukan bahwa Dalam rangka penegakan hukum Pemilu Bawaslu belum optimal dalam meningkatkan kualitas pengawasan hal ini terjadi karena masih banyak tindak pidana pemilu yang tidak dapat dideteksi oleh pengawas pemilu antara lain kasus money politik, intimidasi terhadap pemilih, pelibatan ASN yang masif, Waktu 14 hari kerja bagi Pengawas Pemilihan Umum untuk menangani temuan atau laporan dugaan tindak pidana Pemilu masih belum optimal.

Berdasarkan kesimpulan diatas maka dalam penegakan hukum pidana pemilu, saran yang dapat disampaikan pada penelitian ini adalah: 1) Agar penataan kerangka hukum Pemilihan umum melalui revisi undang-undang tentang Pemilihan Umum dengan lebih mempertegas pengaturan tindak pidana pemilu dalam rumpun pelanggaran pemilu. 2) Agar dilakukan perubahan pengaturan tindak Pidana Pemilu sebagaimana diatur dalam Undang-Undang Pemilu sehingga dapat $100 \%$ diterapkan sehingga proses penegakan hukum pemilu yang dikaitkan dengan waktu penanganan pelanggaran pemilu penerapannya merujuk kepada waktu penanganan yang diatur dalam Kitab Undang-Undang Hukum Acara Pidana (KUHAP).

\section{REFERENSI}

Adonara, F. F. (2015). Prinsip Kebebasan Hakim dalam Memutus Perkara Sebagai Amanat 
Konstitusi Principles of Fredom of Justice in Decidene The Case as a Constitutional Mandate. Jurnal Konstitusi, 12(1), 1-20.

Al-fatih, S. (2020). Electoral Regulation in Indonesia : Is It Modern Law ? Unnes Law Journal, 6(2), 205-216. https://doi.org/https://doi.org/10.15294/ulj.v6i2.41627

Ardipandanto, A. (2019). Permasalahan Penyelenggaraan Pemilu Serentak Tahun 2019. Info Singkat Kajian Singkat Terhadap Isu Aktual Dan Strategis, 11(11), 28.

Aulia, F., \& Al-Fatih, S. (2017). Perbandingan Sistem Hukum Common Law, Civil Law dan Islamic Law dalam Perspektif Sejarah dan Karakteristik Berpikir . Legality : Jurnal Ilmiah Hukum, 25(1), 98-113. http://202.52.52.22/index.php/legality/article/view/5993

Din, M., Rizanizarli, R., \& Jalil, A. (2020). Model Penegakan Hukum Tindak Pidana Pemilu di Provinsi Aceh yang Berkeadilan. Jurnal Penelitian Hukum De JureDe Jure, 20(3), 289300. https://doi.org/ttp://dx.doi.org/10.30641/dejure.2020.V20.289-300

Erdianti, R. N., \& Al-Fatih, S. (2019). Fostering as an Alternative Sanction for Juveniles in the Perspective of Child Protection in Indonesia. JILS (Journal of Indonesian Legal Studies), 4(1), 119-128. https://doi.org/10.15294/JILS.V4I01.29315

Esfandiari, F., \& Fatih, S. Al. (2020). Initiating a Permanent Electoral Body To Resolve Dignified Election Disputes: Assessing the Effectiveness of Gakkumdu. Yustisia Jurnal Hukum, 9(3), 333. https://doi.org/10.20961/yustisia.v9i3.44437

Fahmi, K., Amsari, F., Azheri, B., \& Kabullah, M. I. (2020). Sistem Keadilan Pemilu dalam Penanganan Pelanggaran dan Sengketa Proses Pemilu Serentak 2019 di Sumatera Barat. Jurnal Konstitusi, 17(1), 001. https://doi.org/10.31078/jk1711

Irwansyah. (2020). Penelitian Hukum: Pilihan Metode \& Praktik Penulisan Artikel (A. Yunus (ed.)). Mirra Buana Media.

Likadja, J. A. C. (2015). Memaknai "Hukum Negara (Law Through State)" dalam Bingkai "Negara Hukum (Rechtstaat)." Hasanuddin Law Review, 1(1), 75-86.

http://pasca.unhas.ac.id/ojs/index.php/halrev/article/view/41/40

Mertokusumo, S. (2004). Penemuan Hukum. Liberty.

Mulyadi, D. (2015). Kebijakan Legislasi Tentang Sanksi Pidana Pemilu Legislatif di Indonesia Dalam Prespektif Indonesia. Gramata Publishing.

Prasetyo, T., \& Halim, A. (2005). Politik Hukum Pidana. Pustaka Pelajar.

Rahmatunnisa, M. (2017). Mengapa Integritas Pemilu Penting? Jurnal Bawaslu, 3(1).

Ramadani, G. (2009). Analisis Aspek Metodologi Penelitian. FHUI.

Salabi, A. (2019). Perludem Rekomendasikan Perbaikan Penegakan Hukum Pidana Pemilu. Rumah Pemilu.

Saragih, A. D. A. (2017). Tinjauan Yuridis Pentingnya Pembentukan Peradilan Khusus Dalam Pemilu Serentak Menurut Undang-undang Pemilihan Kepala Daerah. Lex et Societatis, 4(3), 9-15. https://ejournal.unsrat.ac.id/index.php/lexetsocietatis/article/view/15590/15127 
Soekanto, S., \& Mamudji, S. (2015). Penelitian Hukum Normatif: Suatu Tinjauan Singkat (17th ed.). Rajawali Pers.

Surbakti, R. et. a. (2011). Penanganan Sengketa Pemilu. Kemitraan bagi Pembaruan Tata Pemerintahan.

Tanthowi, P. U. (2018). Pelanggaran Pemilu, Penegakan Hukum, dan Penguatan Demokrasi.

Tumpal HS, R. (2019). Beda Persepsi Gakkumdu, Dewi: Perlu Diskusi Mencari Solusi Kelemahan UU. Bawaslu RI. https://www.bawaslu.go.id/en/berita/beda-persepsigakkumdu-dewi-perlu-diskusi-mencari-solusi-kelemahan-uu

Wijayanta, T. (2014). Asas Kepastian Hukum, Keadilan Dan Kemanfaatan Dalam Kaitannya Dengan Putusan Kepailitan Pengadilan Niaga. Jurnal Dinamika Hukum, 14(2), 216-226. https://doi.org/10.20884/1.jdh.2014.14.2.291

Wilar, W. F. (2019). Stakeholder Pemilu Dalam Menyukseskan Pelaksanaan Pemilu Serentak 17 April Tahun 2019. Jurnal Holistik, 12(0), 1-13.

https://ejournal.unsrat.ac.id/index.php/holistik/article/view/23448/23129 